\title{
Assessment of Groundwater Quality along the Cooum River, Chennai, Tamil Nadu, India
}

\author{
N. S. Elangovan ${ }^{1}$ and M. Dharmendirakumar ${ }^{2}$ \\ ${ }^{1}$ Department of Civil Engineering, Jerusalem College of Engineering, Chennai, Tamil Nadu 600 100, India \\ ${ }^{2}$ Department of Applied Science and Technology, Alagappa College of Technology, Anna University, Chennai, \\ Tamil Nadu 600 025, India \\ Correspondence should be addressed to M. Dharmendirakumar; mdkumar@annauniv.edu
}

Received 26 November 2012; Accepted 28 January 2013

Academic Editor: Stefan Tsakovski

Copyright (C) 2013 N. S. Elangovan and M. Dharmendirakumar. This is an open access article distributed under the Creative Commons Attribution License, which permits unrestricted use, distribution, and reproduction in any medium, provided the original work is properly cited.

\begin{abstract}
Groundwater quality in Chennai city along the Cooum river, during the premonsoon (June-July) and postmonsoon (Dec-Jan) for three years, from 2009 to 2011, was analyzed. Groundwater samples were collected from 20 bore wells on either side of the river. The analysis focused on the determination of seven specific water quality parameters, namely, $\mathrm{pH}, \mathrm{EC}, \mathrm{TDS}, \mathrm{BOD}, \mathrm{COD}, \mathrm{Na}$ and $\mathrm{Pb}$, using standard procedures. The statistical analysis, like the mean and standard deviation, coefficient of variance, and correlation, and multilinear regression analysis of the obtained data were carried out. The analysis of the collected samples reveals that the stated water quality parameters have not complied with the WHO standards, and the water is not fit for drinking and domestic purposes. The correlation and multilinear regression analyses suggest that the conductivity has a significant correlation with the other six considered water quality parameters.
\end{abstract}

\section{Introduction}

Groundwater is a natural precious resource that sustains the basic needs of all living creatures. It cannot be created or supplemented electronically or hydrologically or by any other means $[1,2]$. People living on earth suffer without potable water, though the earth is covered by $75 \%$ of water. Groundwater serves as a vital source for domestic, agricultural, and industrial uses $[3,4]$. In Chennai city, the growing urbanization and rapid industrialization lead to the generation of huge quantities of waste water. The uncontrolled discharge of sewage, garbage, and industrial effluents into the downstream of the Cooum river, percolates through the soil and contaminates the Groundwater sources. As per the WHO [5], about $80 \%$ of all the diseases in human beings are caused by impure water. The Cooum river originates in Tiruvallur district, traversing about $70 \mathrm{~km}$ and ends in Chennai city, draining into the Bay of Bengal. Of this $16 \mathrm{~km}$, the study area falls within Chennai city. In Chennai district, the river flows through three corporation zones, namely, Kilpauk, Nungambakkam, and Triplicane.
The Cooum river is $80 \%$ more polluted than the treated sewage [6]. Hence, a periodic assessment of the Groundwater becomes necessary to ensure the suitability of water for drinking. Considering these aspects, the present study focuses on analyzing the specific water quality parameters of some groundwater samples on either side of the Cooum river within the city limits as shown in Figure 1.

\section{Experimental}

2.1. Study Area. The study area, along the Cooum river in Chennai district of Tamil Nadu, India, lies between latitude $13^{\circ} 4^{\prime} 5.18^{\prime \prime}$ north and longitude $80^{\circ} 17^{\prime} 9.06^{\prime \prime}$ east. The Cooum river is the starting point where the municipalities and town Panchayats that lie on either side of the river discharge both treated and untreated industrial effluents and domestic sewage in addition to the bathing of animals, human activities, washing of vehicles directly or by feeder drains into the $16 \mathrm{~km}$ length of the Cooum river [7]. People living near this area depend on bore wells for their daily requirement. The literature survey reveals that no Groundwater studies on bore 
TABLE 1: Detail of sample sites along the left side (SL) of the Cooum river.

\begin{tabular}{lcccc}
\hline Site no. & Area & Latitude/longitude & Depth of bore well (m) & Apparent water quality \\
\hline SL1 & Arumbakkam & $13^{\circ} 4^{\prime} 30.8^{\prime \prime} \mathrm{N} 80^{\circ} 12^{\prime} 29.43^{\prime \prime} \mathrm{E}$ & 33 & Odorless, colorless \\
SL2 & Nungambakkam & $13^{\circ} 3^{\prime} 57.27^{\prime \prime} \mathrm{N} 80^{\circ} 13^{\prime} 56.37^{\prime \prime} \mathrm{E}$ & 34 & Odorless, colorless \\
SL3 & Chintadripet & $13^{\circ} 80^{\circ} 14^{\prime} 55 \mathrm{~N} 42^{\prime \prime} 3^{\prime} 59.60^{\prime \prime} \mathrm{E}$ & 34 & Odorless, colorless \\
SL4 & Chintadripet & $13^{\circ} 4^{\prime} 20.64^{\prime \prime} \mathrm{N} 80^{\circ} 16^{\prime} 11.27^{\prime \prime} \mathrm{E}$ & 35 & Odorless, colorless \\
SL5 & Nungambakkam, & $13^{\circ} 3^{\prime} 32.72^{\prime \prime} \mathrm{N} 80^{\circ} 14^{\prime} 15.82^{\prime \prime} \mathrm{E}$ & 33 & Odorless, colorless \\
SL6 & MMDA Colony & $13^{\circ} 3^{\prime} 59.42^{\prime \prime} \mathrm{N} 80^{\circ} 12^{\prime} 49.54^{\prime \prime} \mathrm{E}$ & 35 & Odorless, colorless \\
SL7 & Choolaimedu & $13^{\circ} 3^{\prime} 34.67^{\prime \prime} \mathrm{N} 80^{\circ} 13^{\prime} 32.62^{\prime \prime} \mathrm{E}$ & 33 & Odorless, colorless \\
SL8 & Chinmaya Nagar & $13^{\circ} 3^{\prime} 42.89^{\prime \prime} \mathrm{N} 80^{\circ} 11^{\prime} 44.15^{\prime \prime} \mathrm{E}$ & 34 & Odorless, colorless \\
SL9 & Vadapalani & $13^{\circ} 3^{\prime} 23.42^{\prime \prime} \mathrm{N} 80^{\circ} 12^{\prime} 20.09^{\prime \prime} \mathrm{E}$ & 33 & Odorless, colorless \\
SL10 & Gopalapuram & $13^{\circ} 3^{\prime} 2.11^{\prime \prime} \mathrm{N} 80^{\circ} 15^{\prime} 22.76^{\prime \prime} \mathrm{E}$ & 32 & Turns yellowish \\
\hline
\end{tabular}

TABLE 2: Detail of sample sites along the right side (SR) of the Cooum river.

\begin{tabular}{lcccc}
\hline Site no. & Area & Latitude/longitude & Depth of bore well (m) & Apparent water quality \\
\hline SR1 & Aayiram Vilakku & $13^{\circ} 3^{\prime} 59.72^{\prime \prime} \mathrm{N} 80^{\circ} 15^{\prime} 28.38^{\prime \prime} \mathrm{E}$ & 34 & Odorless, colorless \\
SR2 & Anna Salai & $13^{\circ} 4^{\prime} 27.13^{\prime \prime} \mathrm{N} 80^{\circ} 16^{\prime} 51.48^{\prime \prime} \mathrm{E}$ & 33 & Odorless, colorless \\
SR3 & Anna Nagar & $13^{\circ} 4^{\prime} 49.15^{\prime \prime} \mathrm{N} 80^{\circ} 12^{\prime} 16.12^{\prime \prime} \mathrm{E}$ & 33 & Odorless, colorless \\
SR4 & Anna Nagar East & $13^{\circ} 5^{\prime} 9.70^{\prime \prime} \mathrm{N} 80^{\circ} 13^{\prime} 13.17^{\prime \prime} \mathrm{E}$ & 33 & Odorless, colorless \\
SR5 & Periamet & $13^{\circ} 4^{\prime} 55.95^{\prime \prime} \mathrm{N} 80^{\circ} 16^{\prime} 8.52^{\prime \prime} \mathrm{E}$ & 34 & Odorless, colorless \\
SR6 & Anna Nagar & $13^{\circ} 5^{\prime} 13.13^{\prime \prime} \mathrm{N} 80^{\circ} 12^{\prime} 12.63^{\prime \prime} \mathrm{E}$ & 33 & Odorless, colorless \\
SR7 & Kilpauk & $13^{\circ} 4^{\prime} 53.24^{\prime \prime} \mathrm{N} 80^{\circ} 14^{\prime} 3.17^{\prime \prime} \mathrm{E}$ & 33 & Odorless, colorless \\
SR8 & Egmore & $13^{\circ} 4^{\prime} 30.59^{\prime \prime} \mathrm{N} 80^{\circ} 15^{\prime} 1.62^{\prime \prime} \mathrm{E}$ & 32 & Odorless, colorless \\
SR9 & Periamet & $13^{\circ} 4^{\prime} 52.49^{\prime \prime} \mathrm{N} 80^{\circ} 15^{\prime} 33.47^{\prime \prime} \mathrm{E}$ & 33 & Odorless, colorless \\
SR10 & Purasavakkam & $13^{\circ} 5^{\prime} 15.12^{\prime \prime} \mathrm{N} 80^{\circ} 14^{\prime} 50.71^{\prime \prime} \mathrm{E}$ & 32 & Odorless, colorless \\
\hline
\end{tabular}

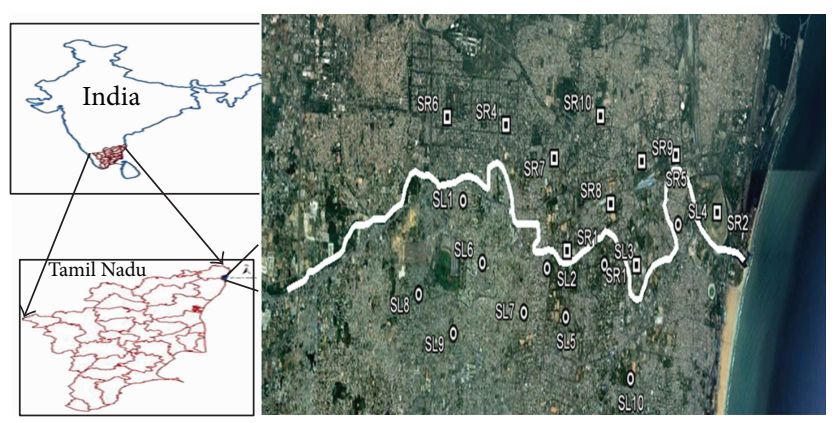

FIGURE 1: A map showing sampling locations along the Cooum river.

wells close to the river were done so far. Hence, the study has been carried out on 20 different sites that cover the area of $16 \times 2 \mathrm{~km}$, which includes 10 sites on the left side of the river and 10 sites on the right side of the river, to assess the impact of the percolation of the river water flow on the Groundwater. The location of the sample sites was given in Tables 1 and 2 .

2.2. Collection of Samples. Water samples were collected from the bore wells at a depth of 32-35 m below the ground level at 20 locations along the Cooum river. Two water samples were collected per year per sampling station covering both pre- and postmonsoon seasons. A total of 120 samples were tested and analyzed for a period of three years (2009-2011).
The collected samples were stored in cleaned and welldried brown polythene glass bottles $(2.5 \mathrm{~L})$, with necessary precautions (APHA, 1995) [8]. These bottles were labeled with respect to the collecting points, date, and time in order to avoid any error between collection and analysis. All the sample collections were immediately preserved in an icebox and brought to the laboratory for determining the specific water quality parameters.

2.3. Sample Analysis. The collected samples were analyzed for specific water quality parameters such as $\mathrm{pH}$, electrical conductivity (EC), total dissolved solids (TDS), biochemical oxygen demand (BOD), chemical oxygen demand (COD), 
TABLE 3: Methods used for analysis of quality parameters for the water samples.

\begin{tabular}{lc}
\hline Quality parameters studied & Methods used \\
\hline $\mathrm{pH}$ & $\mathrm{pH}$ meter \\
Electrical conductivity & Conductivity meter \\
Total dissolved solids & Evaporation method \\
Biochemical oxygen demand & Modified Winkler's method \\
Chemical oxygen demand & Titrated with an excess of $\mathrm{K}_{2} \mathrm{Cr}_{2} \mathrm{O}_{7}$ \\
Sodium & Flame photometry \\
Lead & Atomic absorption spectrometry \\
\hline
\end{tabular}

sodium $(\mathrm{Na})$, and lead $(\mathrm{Pb})$ using standard methods as tabulated in Table 3. The World Health Organisation (WHO) permissible limit of drinking water quality parameters were specified in Table 4 . The observed values of the above specified water quality parameters along the left and right sides of the river were shown in Figures 2(a)-8(a) and 2(b)-8(b) for the pre- and postmonsoon seasons. Tables 5 and 6 summarize the maximum, minimum, mean, and standard deviations and coefficient of variance $(\mathrm{CV} \%)$ found in the different Groundwater samples for the pre- and postmonsoon seasons respectively. The correlation and multi linear regression analyses have also been carried out to find the correlation between the water quality parameters and are listed in Tables 7 and 8.

\section{Results and Discussion}

3.1. $\mathrm{pH}$. $\mathrm{pH}$ is a measure of the concentration of hydrogen ions $\left(\mathrm{H}^{+}\right)$in water. Water with a $\mathrm{pH}$ value below 7 is said to be acidic, and water with a $\mathrm{pH}$ value above 7 is basic or alkaline in nature $[9,10]$. For fish and aquatic life, the protection limit of the $\mathrm{pH}$ ranges from 6.0 to 9.0 The experimental values of the water samples were found to be between 6.71 and 8.31 during the premonsoon and between 6.6 and 7.7 during postmonsoon which are within the prescribed limit as suggested by WHO (Figures 2(a) and 2(b)). This shows that the $\mathrm{pH}$ of the water samples would not affect the domestic and aquatic system. The high $\mathrm{pH}$ value during the premonsoon indicates the surface water contamination resulting from the penetration into the Groundwater. The mean value of $\mathrm{pH}$ up to $7.548 \pm 0.36026$ and $7.2545 \pm 0.284225$ during the preand postmonsoon seasons indicates slight alkalinity nature, presumably due to the seepage of waste water from domestic use and industries. The maximum variance value during the premonsoon CV\% = 5.948777 was found to be higher than that of the postmonsoon season, that is, $\mathrm{CV} \%=4.050786$.

3.2. EC. Electrical conductivity is a measure of concentration of ionized substances that convey electric current in water [11]. The higher EC indicates how strong is current flow based on the amount of total dissolved salts. In the present study EC values were found within the range of $498-2371 \mu \mathrm{S} / \mathrm{cm}$
TABLE 4: Water quality parameters with respect to the WHO standards.

\begin{tabular}{lcc}
\hline S. no & Parameter & WHO \\
\hline 1 & $\mathrm{pH}$ & $7.0-8.5$ \\
2 & Electrical conductivity $(\mathrm{EC})(\mu \mathrm{S} / \mathrm{cm})$ & 1400 \\
3 & Total dissolved solids $(\mathrm{mg} / \mathrm{L})$ & 1000 \\
4 & Bio chemical oxygen demand (BOD) & 5 \\
5 & $(\mathrm{mg} / \mathrm{L})$ & \\
& Chemical oxygen demand (COD) & 10 \\
6 & $(\mathrm{mg} / \mathrm{L})$ & 200 \\
7 & Sodium (mg/L) & 0.01 \\
\hline
\end{tabular}

and $508-2207 \mu \mathrm{S} / \mathrm{cm}$ during pre- and postmonsoon seasons (Figures 3(a) and 3(b)). The mean SR1-SR10 for the preand postmonsoon of 2009-2011 value of EC upto $1523.75 \pm$ $559.89 \mu \mathrm{S} / \mathrm{cm}$ and $1490.05 \pm 465.66 \mu \mathrm{S} / \mathrm{cm}$ during pre- and postmonsoon shows that the higher concentration of EC was due to the higher amount of TDS. The analysis of the study period from 2009 to 2011 shows the increasing level of EC that enhances the level of the ionized substances of the water. The maximum variance value during premonsoon $\mathrm{CV} \%=42.11$ was found to be higher than that of the postmonsoon season, that is, $\mathrm{CV} \%=33.3672$.

3.3. TDS. TDS is a measure of the combined concentration of cations and anions [12]. The major components of TDS include bicarbonate $\left(\mathrm{HCO}_{3}{ }^{-}\right)$, sulphate $\left(\mathrm{SO}_{4}{ }^{2-}\right)$, hydrogen $\left(\mathrm{H}^{+}\right)$, silica $\left(\mathrm{SiO}_{4}\right)$, chlorine $\left(\mathrm{Cl}^{-}\right)$, calcium $\left(\mathrm{Ca}^{+2}\right)$, magnesium $\left(\mathrm{Mg}^{+2}\right)$, sodium $\left(\mathrm{Na}^{+}\right)$, potassium $\left(\mathrm{K}^{+}\right)$, nitrates $\left(\mathrm{NO}_{3}{ }^{-}\right)$, and phosphate $\left(\mathrm{PO}_{4}{ }^{3-}\right)$. The TDS of the Groundwater is mainly due to the vegetable decay and the disposal of effluents from industries. The TDS values of the sampling sites varied from 987 to $2892 \mathrm{mg} / \mathrm{L}$ and 905 to $2716 \mathrm{mg} / \mathrm{L}$ during the pre- and postmonsoon seasons. The present investigation shows that all the samples exceeded the limit prescribed by WHO, except the sample of the site SR10 (Figures 4(a) and 4(b)). The mean values of the TDS were found to be $2073.5 \pm 585.85 \mathrm{mg} / \mathrm{L}$ and $2007.3 \pm 581.92 \mathrm{mg} / \mathrm{L}$ during the pre- and postmonsoon seasons. This reveals the high concentration of the TDS value during the premonsoon due to the evaporation of water. The Maximum variance value during the premonsoon CV\% $=30.38904$ was found to be higher than that of the postmonsoon season that is, $\mathrm{CV} \%=$ 30.64991 .

3.4. BOD. The BOD values indicate the amount of organic waste present in the water [13]. The analyzed $\mathrm{BOD}$ values varied from 4.24 to $8.56 \mathrm{mg} / \mathrm{L}$ and from 4.3 to $8.97 \mathrm{mg} / \mathrm{L}$ during the pre- and postmonsoons, indicating that the value of $\mathrm{BOD}$ is higher during the postmonsoon season, presumably due to the percolation of industrial effluents and domestic wastes into the Groundwater. The sampling sites SL1, SL3, SL4, SR1-SR3, SR8 showed higher BOD values than those permitted by WHO (Figures 5(a) and 5(b)). The mean 


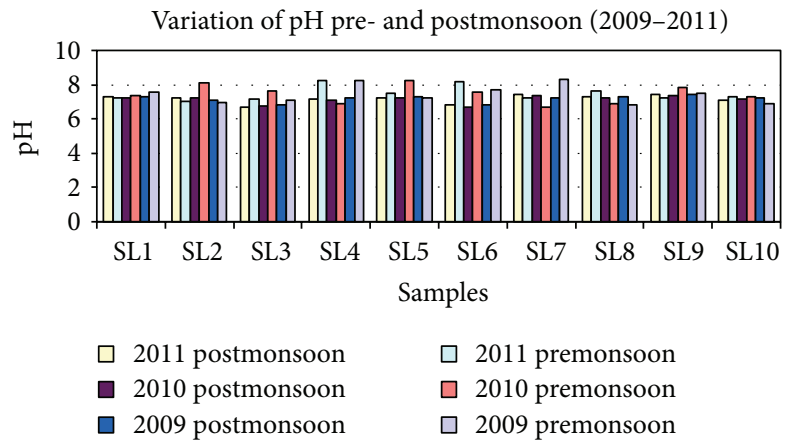

(a)

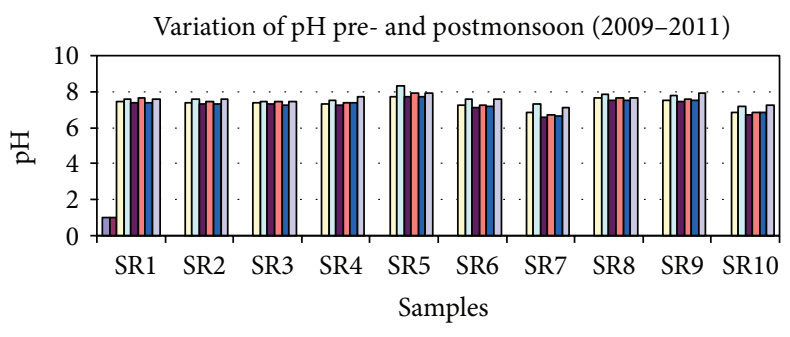

$\begin{array}{ll}\square \text { pH } 2011 \text { postmonsoon } & \square \text { pH } 2011 \text { premonsoon } \\ \square \text { pH } 2010 \text { postmonsoon } & \square \text { pH } 2010 \text { premonsoon } \\ \square \text { pH } 2009 \text { postmonsoon } & \square \text { pH } 2009 \text { premonsoon }\end{array}$

(b)

FIGURE 2: (a) Observations of $\mathrm{pH}$ in water from the sites SL1-SL10 for the pre- and postmonsoon of 2009-2011. (b) Observations of pH in water from the sites SR1-SR10 for the pre- and postmonsoon of 2009-2011.

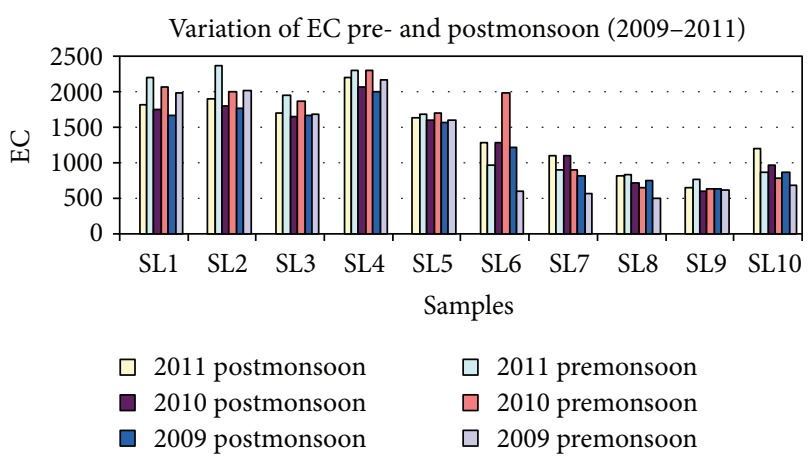

(a)

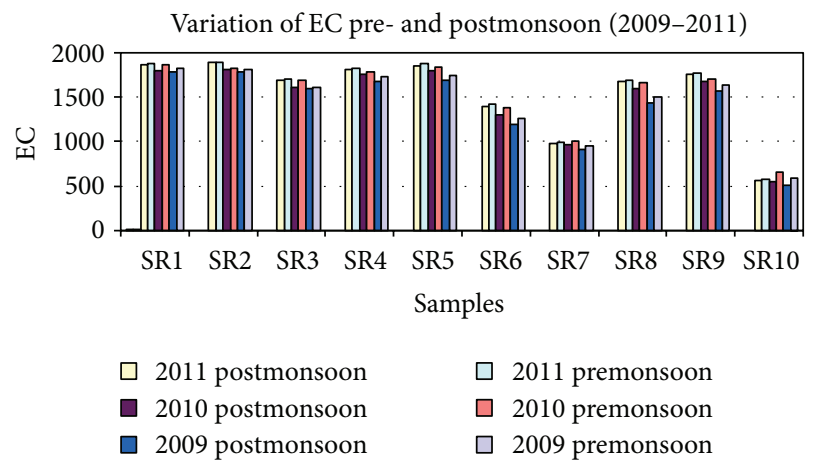

(b)

FIGURE 3: (a) Observations of EC in water from the sites SL1-SL10 for the pre- and postmonsoon of 2009-2011. (b) Observations of EC in water from the sites SR1-SR10 for the pre- and postmonsoon of 2009-2011.

value of BOD was $6.8995 \pm 1.34 \mathrm{mg} / \mathrm{L}$ and $6.755 \pm 1.27 \mathrm{mg} / \mathrm{L}$ during the pre- and postmonsoons which shows the presence of soluble salts in the sampling sites. The maximum variance value during the premonsoon of $\mathrm{CV} \%=20.38$ was found to be higher than the postmonsoon seasons $C V \%=19.32$.

3.5. COD. The COD level indicates the amount of toxicity in water [14]. The observed values of the COD in both the seasons from all the sampling sites were found to exceed the permissible limit (Figures 6(a) and 6(b)). The analyzed COD values of the sampling sites varied from 11.1 to $24.8 \mathrm{mg} / \mathrm{L}$ and from 10.3 to $24.6 \mathrm{mg} / \mathrm{L}$ for the pre- and postmonsoon seasons. The observed COD value was higher during premonsoon the season, presumably due to the decreased flow of water during this period. The mean value of $19.72 \pm 3.9 \mathrm{mg} / \mathrm{L}$ and $18.645 \pm 3.99 \mathrm{mg} / \mathrm{L}$ indicates that the COD values were above the desirable limit during the pre- and postmonsoon seasons. The maximum variance value during the premonsoon $\mathrm{CV} \%$ $=20.3865$ was found to be higher than the postmonsoon seasons $\mathrm{CV} \%=19.32$. The analyzed $\mathrm{COD}$ values were found to be higher than the BOD values. This indicates the ample presence of chemically oxidizable substances of which the majority are nonbiodegradable [15].

3.6. Na. The higher concentration of sodium in the Groundwater causes cardiovascular diseases and toxemia in pregnant women [16]. The sodium of the water samples collected lies in the range of $130-313 \mathrm{mg} / \mathrm{L}$ and $120-313 \mathrm{mg} / \mathrm{L}$ during the pre- and postmonsoon seasons. The mean values of $230 \pm$ $57.54 \mathrm{mg} / \mathrm{L}$ and $216.3 \pm 58.22 \mathrm{mg} / \mathrm{L}$ during the pre- and postmonsoon seasons show that domestic discharge may contribute to increase the sodium content through leaching [17]. The present analysis shows that the sampling points SL1SL4, SR1-SR5, SR8, SR9 (Figures 7(a) and 7(b)) exceed the permissible value. The maximum variance value during the premonsoon of $\mathrm{CV} \%=25.01$ was found lower than that of the postmonsoon season, that is, $\mathrm{CV} \%=28.14$.

3.7. $\mathrm{Pb}$. Lead $(\mathrm{Pb})$ is a heavy metal gets into the environment through waste water or solid waste disposal. High concentration of lead causes kidney damage, bone damage, and nervous disorder [18]. The lead concentrations in 

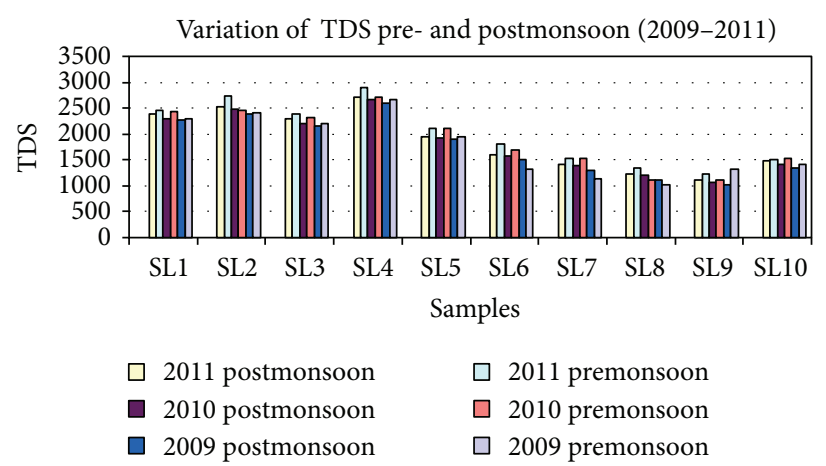

(a)
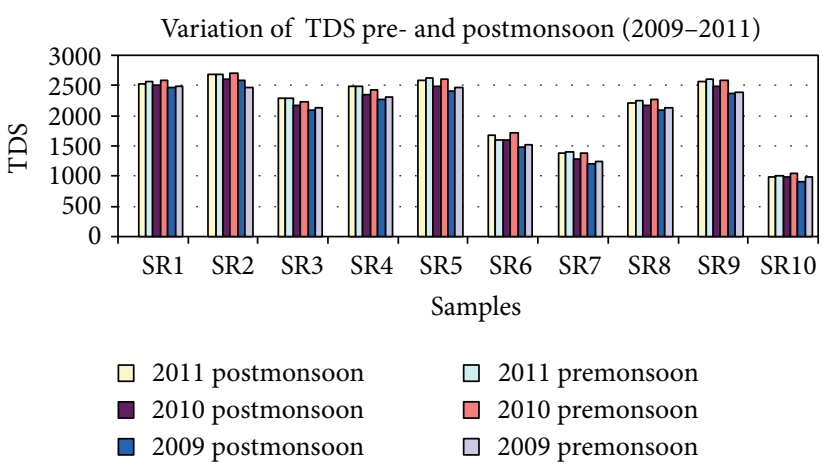

(b)

FIgURE 4: (a) Observations of TDS in water from the sites SL1-SL10 for the pre- and postmonsoons of 2009-2011. (b) Observations of TDS in water from the sites SR1-SR10 for the pre- and postmonsoon of 2009-2011.

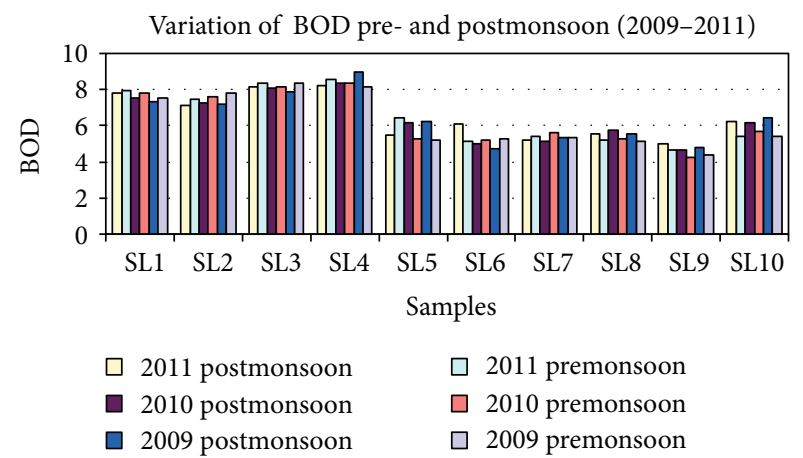

(a)

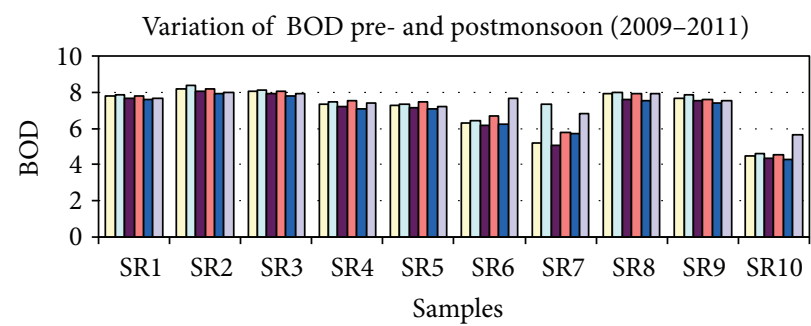

$\square 2011$ postmonsoon

2010 postmonsoon

2009 postmonsoon $\square \quad 2011$ premonsoon
$\square \quad 2010$ premonsoon
$\square \quad 2009$ premonsoon

(b)

FIGURE 5: (a) Observations of BOD in water from the sites SL1-SL10 for the pre- and postmonsoon of 2009-2011. (b) Observations of BOD in water from the sites SR1-SR10 for the pre- and postmonsoon of 2009-2011.

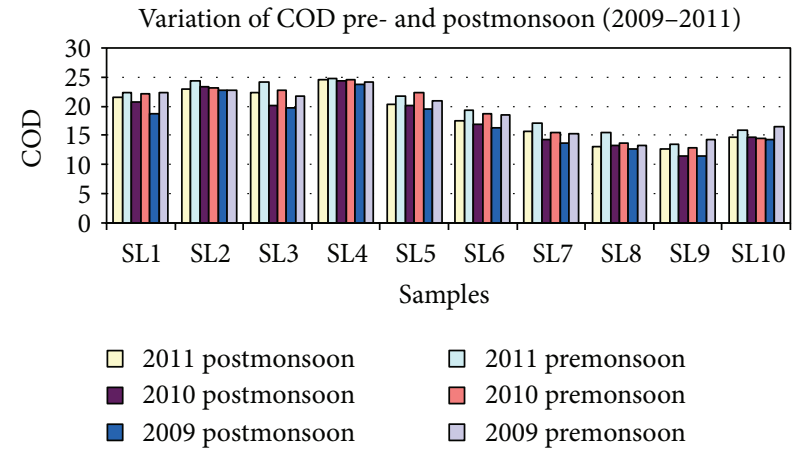

(a)
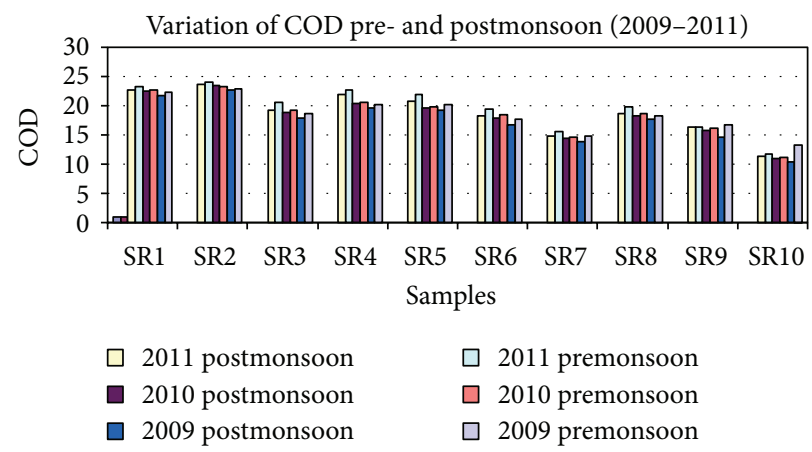

(b)

FIgURE 6: (a) Observations of COD in water from the sites SL1-SL10 for the pre- and postmonsoon of 2009-2011. (b) Observations of COD in water from the sites SR1-SR10 for the pre- and postmonsoon of 2009-2011.

the samples were found to be between 0.025 and $0.087 \mathrm{mg} / \mathrm{L}$ and between 0.03 and $0.083 \mathrm{mg} / \mathrm{L}$ for the pre- and postmonsoon seasons, respectively (Figures $8(\mathrm{a})$ and $8(\mathrm{~b})$ ). The present study shows that all the samples obtained from the adjoining bore wells were above the permissible limit; the mean value of $\mathrm{Pb}$ is above the limit due to the seepage of the Cooum water into the Groundwater and indicats its toxicity during the pre- and postmonsoon of seasons $(0.0642 \pm 0.014 \mathrm{mg} / \mathrm{L}$ and $0.0578 \pm 0.014 \mathrm{mg} / \mathrm{L})$. The maximum variance found during the postmonsoon of $\mathrm{CV} \%=26.80$ 
TABLE 5: Statistics of three years (2009-2011) groundwater quality data-premonsoon.

\begin{tabular}{|c|c|c|c|c|c|c|c|c|}
\hline \multicolumn{9}{|c|}{ Premonsoon } \\
\hline Parameter & Year & $\mathrm{pH}$ & $\mathrm{EC}(\mu \mathrm{S} / \mathrm{cm})$ & TDS (mg/L) & $\mathrm{BOD}(\mathrm{mg} / \mathrm{L})$ & $\operatorname{COD}(\mathrm{mg} / \mathrm{L})$ & $\mathrm{Na}(\mathrm{mg} / \mathrm{L})$ & $\mathrm{Pb}(\mathrm{mg} / \mathrm{L})$ \\
\hline \multirow{3}{*}{ Max } & 2009 & 8.31 & 2173 & 2677 & 8.34 & 24.2 & 287 & 0.081 \\
\hline & 2010 & 8.26 & 2296 & 2713 & 8.35 & 24.6 & 303 & 0.083 \\
\hline & 2011 & 8.3 & 2371 & 2892 & 8.56 & 24.8 & 313 & 0.087 \\
\hline \multirow{3}{*}{ Min } & 2009 & 6.85 & 498 & 987 & 4.39 & 13.3 & 130 & 0.025 \\
\hline & 2010 & 6.71 & 631 & 1048 & 4.24 & 11.1 & 137 & 0.03 \\
\hline & 2011 & 7.04 & 583 & 1010 & 4.64 & 11.8 & 150 & 0.036 \\
\hline \multirow{3}{*}{ Mean } & 2009 & 7.51 & 1355 & 1894.15 & 6.8135 & 18.73 & 219.75 & 0.0585 \\
\hline & 2010 & 7.4185 & 1515.95 & 2029 & 6.74 & 18.755 & 226.55 & 0.055 \\
\hline & 2011 & 7.548 & 1523.75 & 2073.5 & 6.8995 & 19.72 & 230 & 0.0642 \\
\hline \multirow{3}{*}{ Std. } & 2009 & 0.41391 & 570.724 & 575.614 & 1.27868 & 3.4278 & 53.18 & 0.01494 \\
\hline & 2010 & 0.44131 & 536.77 & 577.915 & 1.37405 & 4.0111 & 55.006 & 0.014567 \\
\hline & 2011 & 0.36026 & 559.887 & 585.852 & 1.34849 & 3.9107 & 57.544 & 0.014468 \\
\hline \multirow{3}{*}{ CV\% } & 2009 & 5.51145 & 42.11985 & 30.38904 & 18.76686 & 18.30112 & 24.20023 & 25.53846 \\
\hline & 2010 & 5.9487 & 35.40816 & 28.48275 & 20.3865 & 21.38683 & 25.40013 & 26.48545 \\
\hline & 2011 & 4.7729 & 36.74402 & 28.25426 & 19.54475 & 19.83114 & 25.01913 & 22.53583 \\
\hline
\end{tabular}
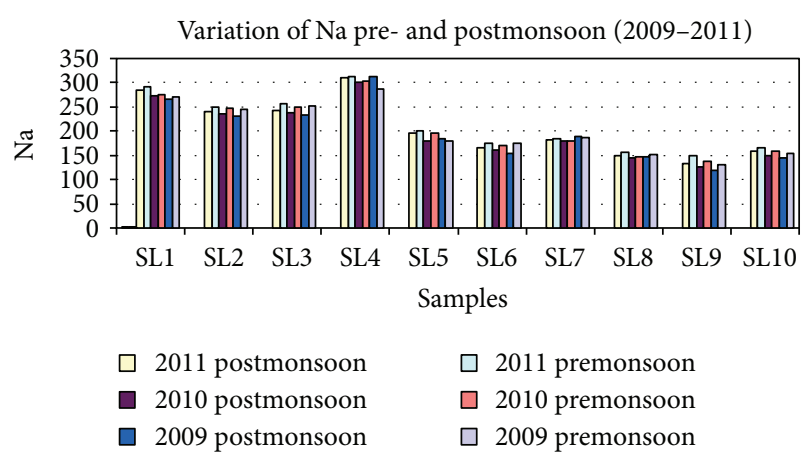

(a)

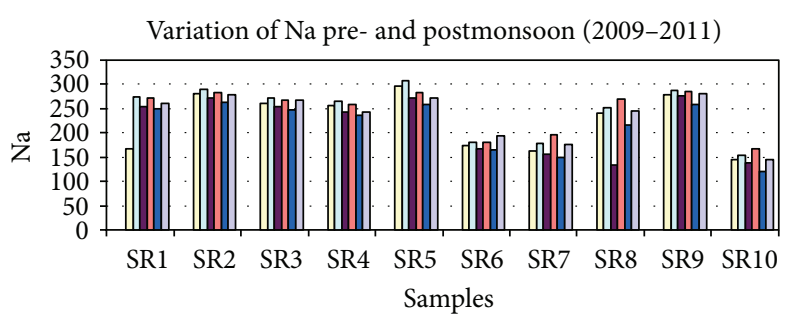

$\square 2011$ postmonsoon

2010 postmonsoon

口 2009 postmonsoon

(b)

FIgURE 7: (a) Observations of Na in water from the sites SL1-SL10 for the pre- and postmonsoon of 2009-2011. (b) Observations of Na in water from the sites SL1-SL10 for the pre- and postmonsoon of 2009-2011.

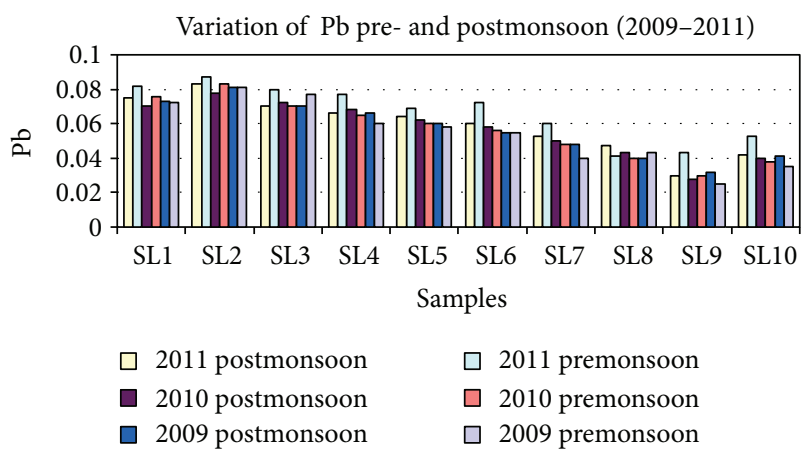

(a)

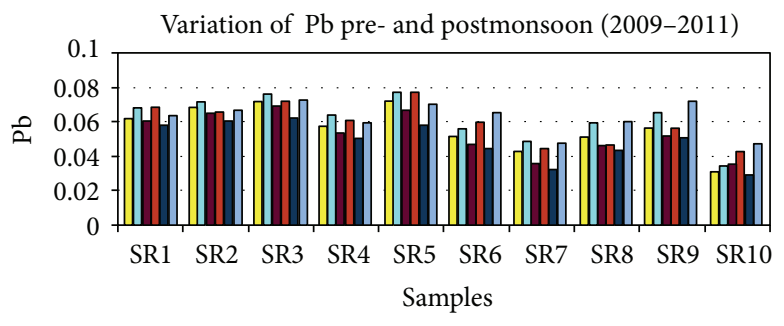

$\begin{array}{ll}\square \text { 2011 postmonsoon } & \square 2011 \text { premonsoon } \\ \square \text { 2010 postmonsoon } & \square 2010 \text { premonsoon } \\ \square \text { 2009 postmonsoon } & \square 2009 \text { premonsoon }\end{array}$

(b)

FIgURE 8: (a) Observations of Pb in water from the sites SL1-SL10 for the pre- and postmonsoon of 2009-2011. (b) Observations of Pb in water from the sites SR1-SR10 for the pre- and postmonsoon of 2009-2011. 
TABLE 6: Statistics of three years (2009-2011) groundwater quality data-postmonsoon.

\begin{tabular}{|c|c|c|c|c|c|c|c|c|}
\hline \multicolumn{9}{|c|}{ Postmonsoon } \\
\hline Parameter & Year & $\mathrm{pH}$ & $\mathrm{EC}(\mu \mathrm{S} / \mathrm{cm})$ & TDS (mg/L) & $\mathrm{BOD}(\mathrm{mg} / \mathrm{L})$ & $\mathrm{COD}(\mathrm{mg} / \mathrm{L})$ & $\mathrm{Na}(\mathrm{mg} / \mathrm{L})$ & $\mathrm{Pb}(\mathrm{mg} / \mathrm{L})$ \\
\hline \multirow{3}{*}{ Max } & 2009 & 7.7 & 2004 & 2605 & 8.97 & 23.7 & 313 & 0.081 \\
\hline & 2010 & 7.7 & 2073 & 2673 & 8.39 & 24.3 & 300 & 0.08 \\
\hline & 2011 & 7.75 & 2207 & 2716 & 8.25 & 24.6 & 310 & 0.083 \\
\hline \multirow{3}{*}{ Min } & 2009 & 6.7 & 508 & 905 & 4.3 & 10.3 & 120 & 0.03 \\
\hline & 2010 & 6.6 & 557 & 981 & 4.37 & 10.9 & 127 & 0.03 \\
\hline & 2011 & 6.7 & 567 & 993 & 4.46 & 11.3 & 133 & 0.03 \\
\hline \multirow{3}{*}{ Mean } & 2009 & 7.222 & 1358.1 & 1873.35 & 6.6555 & 17.365 & 207.45 & 0.0528 \\
\hline & 2010 & 7.187 & 1422.35 & 1944.08 & 6.644 & 18.072 & 207.7 & 0.055 \\
\hline & 2011 & 7.2545 & 1490.05 & 2007.3 & 6.755 & 18.645 & 216.3 & 0.0578 \\
\hline \multirow{3}{*}{ Std. } & 2009 & 0.2658 & 453.16 & 574.18 & 1.25741 & 3.9141 & 56.049 & 0.014152 \\
\hline & 2010 & 0.29113 & 455.259 & 570.488 & 1.28389 & 3.987 & 58.448 & 0.01407 \\
\hline & 2011 & 0.284225 & 465.6663 & 581.9234 & 1.268574 & 3.997562 & 58.22199 & 0.014413 \\
\hline \multirow{3}{*}{ CV\% } & 2009 & 3.680421 & 33.3672 & 30.64991 & 18.8928 & 22.54017 & 27.01808 & 26.80303 \\
\hline & 2010 & 4.050786 & 32.00752 & 29.34488 & 19.32405 & 22.06175 & 28.14059 & 25.58182 \\
\hline & 2011 & 3.917913 & 31.25172 & 28.99036 & 18.77978 & 21.4404 & 26.91724 & 24.93599 \\
\hline
\end{tabular}

TABLE 7: Correlation coefficient $(r)$ for different water quality parameters-premonsoon.

\begin{tabular}{|c|c|c|c|c|c|c|c|}
\hline Parameter & $\mathrm{pH}$ & EC & TDS & BOD & COD & $\mathrm{Na}$ & $\mathrm{Pb}$ \\
\hline \multicolumn{8}{|c|}{2009 premonsoon } \\
\hline $\mathrm{pH}$ & 1 & & & & & & \\
\hline EC & 0.251 & 1 & & & & & \\
\hline TDS & 0.331 & 0.96 & 1 & & & & \\
\hline BOD & 0.217 & 0.831 & 0.785 & 1 & & & \\
\hline COD & 0.226 & 0.867 & 0.884 & 0.668 & 1 & & \\
\hline $\mathrm{Na}$ & 0.449 & 0.926 & 0.895 & 0.878 & 0.768 & 1 & \\
\hline $\mathrm{Pb}$ & 0.103 & 0.761 & 0.819 & 0.829 & 0.709 & 0.821 & 1 \\
\hline \multicolumn{8}{|c|}{2010 premonsoon } \\
\hline $\mathrm{pH}$ & 1 & & & & & & \\
\hline $\mathrm{EC}$ & 0.437 & 1 & & & & & \\
\hline TDS & 0.447 & 0.896 & 1 & & & & \\
\hline BOD & 0.192 & 0.782 & 0.900 & 1 & & & \\
\hline COD & 0.442 & 0.911 & 0.863 & 0.762 & 1 & & \\
\hline $\mathrm{Na}$ & 0.238 & 0.811 & 0.941 & 0.932 & 0.731 & 1 & \\
\hline $\mathrm{Pb}$ & 0.420 & 0.846 & 0.816 & 0.758 & 0.835 & 0.750 & 1 \\
\hline \multicolumn{8}{|c|}{2011 premonsoon } \\
\hline $\mathrm{pH}$ & 1 & & & & & & \\
\hline $\mathrm{EC}$ & 0.191 & 1 & & & & & \\
\hline TDS & 0.352 & 0.950 & 1 & & & & \\
\hline BOD & 0.185 & 0.876 & 0.859 & 1 & & & \\
\hline $\mathrm{COD}$ & 0.229 & 0.896 & 0.873 & 0.764 & 1 & & \\
\hline $\mathrm{Na}$ & 0.370 & 0.896 & 0.947 & 0.888 & 0.767 & 1 & \\
\hline $\mathrm{Pb}$ & 0.186 & 0.856 & 0.855 & 0.694 & 0.874 & 0.766 & 1 \\
\hline
\end{tabular}


TABLE 8: Correlation coefficient $(r)$ for different water quality parameters-postmonsoon.

\begin{tabular}{|c|c|c|c|c|c|c|c|}
\hline Parameter & $\mathrm{pH}$ & EC & TDS & $\mathrm{BOD}$ & COD & $\mathrm{Na}$ & $\mathrm{Pb}$ \\
\hline \multicolumn{8}{|c|}{2009 postmonsoon } \\
\hline $\mathrm{pH}$ & 1 & & & & & & \\
\hline EC & 0.3 & 1 & & & & & \\
\hline TDS & 0.412 & 0.975 & 1 & & & & \\
\hline BOD & 0.348 & 0.88 & 0.899 & 1 & & & \\
\hline COD & 0.182 & 0.935 & 0.89 & 0.811 & 1 & & \\
\hline $\mathrm{Na}$ & 0.399 & 0.915 & 0.948 & 0.909 & 0.808 & 1 & \\
\hline $\mathrm{Pb}$ & 0.084 & 0.832 & 0.78 & 0.676 & 0.827 & 0.748 & 1 \\
\hline \multicolumn{8}{|c|}{2010 postmonsoon } \\
\hline $\mathrm{pH}$ & 1 & & & & & & \\
\hline $\mathrm{EC}$ & 0.363 & 1 & & & & & \\
\hline TDS & 0.445 & 0.972 & 1 & & & & \\
\hline BOD & 0.405 & 0.884 & 0.921 & 1 & & & \\
\hline COD & 0.244 & 0.933 & 0.893 & 0.829 & 1 & & \\
\hline $\mathrm{Na}$ & 0.333 & 0.846 & 0.886 & 0.809 & 0.762 & 1 & \\
\hline $\mathrm{Pb}$ & 0.186 & 0.849 & 0.808 & 0.747 & 0.857 & 0.781 & 1 \\
\hline \multicolumn{8}{|c|}{2011 postmonsoon } \\
\hline $\mathrm{pH}$ & 1 & & & & & & \\
\hline $\mathrm{EC}$ & 0.392 & 1 & & & & & \\
\hline TDS & 0.325 & 0.974 & 1 & & & & \\
\hline BOD & 0.310 & 0.914 & 0.892 & 1 & & & \\
\hline COD & 0.164 & 0.895 & 0.935 & 0.812 & 1 & & \\
\hline $\mathrm{Na}$ & 0.363 & 0.879 & 0.843 & 0.818 & 0.730 & 1 & \\
\hline $\mathrm{Pb}$ & 0.167 & 0.821 & 0.846 & 0.723 & 0.853 & 0.734 & 1 \\
\hline
\end{tabular}

was higher than that of the premonsoon season, that is, $\mathrm{CV} \%=26.48$.

3.8. Statistical Analysis. The statistical relationship between the water quality parameters was examined, through the analysis of the linear correlation method [19, 20]. The correlation coefficient $r$ between two parameters, $x$ and $y$, is determined using the following equation:

$$
r=\frac{n \sum x y-\sum x \sum y}{\sqrt{\left[n \sum x^{2}-\left(\sum x\right)^{2}\right]\left[n \sum y^{2}-\left(\sum y\right)^{2}\right]}},
$$

where $x=$ values of the $x$-variable; $y=$ values of the $y$-variable; $n=$ number of data points.

A positive correlation exists when an increase in the value of one parameter is associated with a corresponding increase in the value of another parameter. The correlation matrices for all the samples of three years during pre- and postmonsoon seasons are listed in Tables 7 and 8. According to the guidelines, the correlation is good if $r>0.6$ and marginal if $0.47<r<0.6$. The conductivity shows a significant correlation with the other parameters, like TDS, BOD, $\mathrm{COD}, \mathrm{Na}, \mathrm{Pb}$ with $(r>0.7610)$ and $(r>0.821)$ during the pre- and postmonsoon seasons except the $\mathrm{pH}$. The correlation between the $\mathrm{pH}$ and $\mathrm{Na}(r>0.278)$ and $(r>$ 0.333 ) during the pre- and postmonsoons indicates the level of bicarbonate and carbonate of sodium in the Groundwater samples, and hence, the presence of alkanity of the water [21]. The BOD and COD shows a good correlation with $(r>0.668)$ and $(r>0.676)$ during pre- and postmonsoons. The high degree of association between the TDS and $\mathrm{Na}(r>0.926$ $\& r>0.843)$ during the pre- and postmonsoon seasons indicates the anthropogenic activities such as discharge of sewage, which percolates and mixes with Groundwater [22].

Multivariate methods like cluster analysis, factor analysis, principal component analysis, discriminate analysis, neuron net classification, and multiple regression analysis have been successfully used in water quality analysis without much loss of information to a reasonably manageable data set [23-25]. In the present study, the statistical multiple regression models have been used for predicting the correlation between the independent variables and the dependent variable. However, multiple regression is very sensitive to outliers, and models developed for one area may not be suitable for different area [26]. Despite its limitations, the multiple regression is used to evaluate Groundwater samples, since, it generates minimum data set of indicators and is also easy to implement and interpret [27]. The six selected independent variables $\mathrm{pH}$, TDS, BOD, COD, $\mathrm{Na}$, and $\mathrm{Pb}$ and a dependent variable EC were used as input data in the following multiple linear regression equation [28, 29]. Electrical conductivity is selected as a dependent variable based on the correlation analysis studies. The following equation predicts whether 
TABLE 9: Regression equations based on analyzed parameters.

\begin{tabular}{|c|c|c|c|}
\hline Year & Regression equation & $R^{2}$ value & $F$ value \\
\hline \multicolumn{4}{|c|}{ Premonsoon } \\
\hline 2009 & $\begin{array}{c}\mathrm{EC}=36.358 * \mathrm{pH}+0.807 * \mathrm{TDS}+107.888 * \mathrm{BOD}+24.851 * \mathrm{COD}-3.528 * \mathrm{Na}+6124.594 * \mathrm{~Pb} \\
-1231.212\end{array}$ & 0.958 & 49.555 \\
\hline 2010 & $\begin{array}{c}\mathrm{EC}=2.818 * \mathrm{pH}+0.211 * \mathrm{TDS}-94.336 * \mathrm{BOD}+71.715 * \mathrm{COD}+2.966 * \mathrm{Na}+6154.062 * \mathrm{~Pb}- \\
671.780\end{array}$ & 0.892 & 17.981 \\
\hline 2011 & $\begin{array}{c}\mathrm{EC}=-184.985 * \mathrm{pH}+0.571 * \mathrm{TDS}+66.079 * \mathrm{BOD}+31.193 * \mathrm{COD}+0.332 * \mathrm{Na}+1575.589 * \mathrm{~Pb} \\
+487.066\end{array}$ & 0.945 & 37.07 \\
\hline \multicolumn{4}{|c|}{ Postmonsoon } \\
\hline 2009 & $\begin{array}{rl}\mathrm{EC}=-86.422 * \mathrm{pH}+0.594 * \mathrm{TDS}+4.994 & * \mathrm{BOD}+25.715 * \mathrm{COD}-0.229 * \mathrm{Na}+2456.061 * \mathrm{~Pb} \\
& +306.783\end{array}$ & 0.977 & 91.861 \\
\hline 2010 & $\begin{array}{c}\mathrm{EC}=-45.855 * \mathrm{pH}+0.683 * \mathrm{TDS}-30.021 * \mathrm{BOD}+25.132 * \mathrm{COD}-0.619 * \mathrm{Na}+3254.098 * \mathrm{~Pb} \\
+119.508\end{array}$ & 0.969 & 67.6 \\
\hline 2011 & $\begin{array}{rl}\mathrm{EC}=-17.058 * \mathrm{pH}+0.495 * \mathrm{TDS}-10.607 & * \mathrm{BOD}+36.501 * \mathrm{COD}-0.134 * \mathrm{Na}+1181.900 * \mathrm{~Pb} \\
& -476.028\end{array}$ & 0.969 & 68.523 \\
\hline
\end{tabular}

the dependent variable EC is related to more than one independent variable. Consider the following:

$$
Y=\beta_{0}+\beta_{1} X_{1}+\beta_{2} X_{2}+\cdots \beta_{n} X_{n},
$$

where $X_{1}, X_{2}$, and $X_{n}$ denotes the independent variable, $Y$ stands for the dependent variable, $\beta_{0}$ represents the intercept $\beta_{1}$, and $\beta_{n}$ represents the regression coefficients of the variables.

The multilinear regression analysis was carried out by using the IBM Statistical Package for Social Science (SPSS) software. The estimated $R^{2}$ value and $F$ values of this model are represented in Table 9. The high $R^{2}\left(R^{2}>0.892 \& R^{2}>\right.$ $0.969)$ during the pre- and postmonsoon seasons indicates that the conductivity has a very good correlation with the other chosen parameters. The variance ratio of the $F$ values is high indicating a significant correlation of EC with the other parameters.

\section{Conclusion}

The results of the study indicate that the bore wells in the adjoining areas of the Cooum river are highly polluted, and hence the groundwater of the study area is unfit for domestic use. The analysis in respect of seven parameters, namely, $\mathrm{pH}, \mathrm{EC}, \mathrm{TDS}, \mathrm{BOD}, \mathrm{COD}, \mathrm{Na}$, and $\mathrm{Pb}$, reveals that more than $90 \%$ of the water samples have exceeded the drinking water permissible limit prescribed by the WHO, except the $\mathrm{pH}$. The result of the correlation and multilinear regression analysis shows that the conductivity has high significant correlation with the other parameters. The concentrations of EC, TDS, COD, $\mathrm{Na}$ and $\mathrm{Pb}$ increased every consecutive year, compared to the first year of the study period. This indicates the increase in the pollution load due to the intrusion of domestic sewage and industrial effluents into the Groundwater. Hence, consistent monitoring measures are essential to assess the impact of the percolation of the wastewater, causing contamination of the groundwater in the study area, and a preventive mechanism coupled with remedial measures is necessary for the benefit of mankind.

\section{Conflict of Interests}

The authors declare no conflict of interests or financial disclosures relevant to this paper.

\section{References}

[1] K. Brindha and L. Elango, "Hydrochemical characteristics of groundwater for domestic and irrigation purposes in Madhuranthakam, Tamil Nadu, India," Earth Sciences Research Journal, vol. 15, no. 2, pp. 101-108, 2011.

[2] L. S. Sathiyamurthy, "Water management-our ancestors knew it well," The Hindu, October 2012.

[3] A. A. Jameel and J. Sirajudeen, "Risk assessment of physicochemical contaminants in groundwater of pettavaithalai area, Tiruchirappalli, Tamilnadu-India," Environmental Monitoring and Assessment, vol. 123, no. 1-3, pp. 299-312, 2006.

[4] S. Rengaraj, T. Elampooranan, L. Elango, and V. Ramalingam, "Groundwater quality in suburban regions of Madras city, India," Journal of Pollution Research, vol. 15, no. 4, pp. 325-328, 1996.

[5] WHO Guidelines for Drinking Water, vol. 1, WHO, Geneva, Switzerland, 1984.

[6] http://articles.timesofindia.indiatimes.com/.

[7] P. Arockia Sahayaraj and K. Ayyadurai, "Bioaccumulation of lead in milk of buffaloes from Cooum river belt in Chennai," Journal of Environmental Biology, vol. 30, no. 5, pp. 651-654, 2009.

[8] APHA, Standard Methods for Examination of Water and Wastewater, American Public Health Association, Washington, DC, USA, 19th edition, 1995.

[9] R. K. Trivedy and P. K. Goel, Chemical and Biological Methods for Water Pollution Studies, Environmental Publication, Karad, India, 1986. 
[10] C. C. Harilal, A. Hashim, P. R. Arun, and S. Baji, "Hydrogeochemistry of two rivers of Kerala with special reference to drinking water quality," Ecology, Environment and Conservation, vol. 10, no. 2, pp. 187-192, 2004.

[11] N. Kumar and D. K. Sinha, "Drinking water quality management through correlation studies among various physicochemical parameters: A case study," International Journal of Environmental Sciences, vol. 1, no. 2, pp. 253-259, 2010.

[12] S. G. Daraigan, A. S. Wahdain, A. S. BaMosa, and M. H. Obid, "Linear correlation analysis study of drinking water quality data for AlMukalla City, Hadhramout, Yemen," International Journal of Environmental Sciences, vol. 1, no. 7, pp. 1692-1701, 2011.

[13] K. Usharani, K. Umarani, P. M. Ayyasamy, K. Shanthi, and P. Lakshmanaperumalsamy, "Physico-chemical and bacteriological characteristics of Noyyal River and Ground Water Quality of Perur, India," Journal of Applied Sciences \& Environmental Management, vol. 14, no. 2, pp. 29-35, 2010.

[14] V. T. Patil and P. R. Patil, "Groundwater quality of open wells and tube wells around amalner town of jalgaon District, Maharashtra, India," E-Journal of Chemistry, vol. 8, no. 1, pp. 5358, 2011.

[15] P. Raja, M. A. Amarnath, R. Elangovan, and M. Palanivel, "Evaluation of physical and chemical parameters of river Kaveri, Tiruchirappalli, Tamil Nadu, India," Journal of Environmental Biology, vol. 29, no. 5, pp. 765-768, 2008.

[16] M. C. Shah, P. G. Shilpkar, and P. B. Acharya, "Ground water quality of Gandhinagar Taluka, Gujarat, India," E-Journal of Chemistry, vol. 5, no. 3, pp. 435-446, 2008.

[17] C. Prabakar, K. Saleshrani, D. Dhanasekaran, K. Tharmaraj, and K. B. Askaran, "Seasonal variation in phsio-chemical parameters of Walajapet, Vellore district, Tamil Nadu," International Journal of Current Life Sciences, vol. 1, no. 6, pp. 039-043, 2011.

[18] G. R. Bhagure and S. R. Mirgane, "Heavy metal concentrations in groundwaters and soils of Thane Region of Maharashtra, India," Environmental Monitoring and Assessment, vol. 173, no. 1-4, pp. 643-652, 2011.

[19] S. M. Yahya and H. N. A. Aziz-ur-Rahman, "Assessment of seasonal and polluting effects on the quality of River Water by using regression analysis: a case study of River Indus in Province of Sindh, Pakistan," International Journal of Environmental Protection, vol. 2, pp. 10-16, 2012.

[20] S. A. Antony, M. Balakrishnan, S. Gunasekaran, and R. K. Natarajan, "A correlation study of the ground water quality in the Manali Petroleum Industrial Region in Tamil Nadu, India," Indian Journal of Science and Technology, vol. 1, no. 6, pp. 1-11, 2008.

[21] J. K. Pathak, M. Alam, and S. Sharma, "Interpretation of groundwater quality using multivariate statistical technique in Moradabad City, Western Uttar Pradesh State, India," E-Journal of Chemistry, vol. 5, no. 3, pp. 607-619, 2008.

[22] G. Raja and P. Venkatesan, "Assessment of groundwater pollution and its impact in and around Punnam area of Karur District, Tamilnadu, India," E-Journal of Chemistry, vol. 7, no. 2, pp. 473-478, 2010.

[23] P. Praus, "Water quality assessment using SVD-based principal component analysis of hydrological data," Water $S A$, vol. 31, no. 4, pp. 417-422, 2005.

[24] A. F. M. Alkarkhi, "Assessment of surface water through multivariate analysis," Journal of Sustainable Development, vol. 1, no. 3, pp. 27-33, 2008.
[25] M. Das, A. Kumar, M. Mohapatra, and S. D. Muduli, "Evaluation of drinking quality of groundwater through multivariate techniques in urban area," Environmental Monitoring and Assessment, vol. 166, no. 1-4, pp. 149-157, 2010.

[26] A. Keshavarzi and F. Sarmadian, "Comparison of artificial neural network and multivariate regression methods in prediction of soil cation exchange capacity," World Academy of Science, Engineering \& Technology, vol. 72, pp. 495-500, 2010.

[27] I. Chenini and S. Khemiri, "Evaluation of ground water quality using multiple linear regression and structural equation modeling," International Journal of Environmental Science and Technology, vol. 6, no. 3, pp. 509-519, 2009.

[28] "Multiple Regression," http://ordination.okstate.edu/MULTIPLE.htm.

[29] Abdul Saleem, M. N. Dandigi, and K. Vijay Kumar, "Correlation-regression model for physico-chemical quality of groundwater in the South Indian city of Gulbarga," African Journal of Environmental Science and Technology, vol. 6, no. 9, pp. 353-364, 2012. 

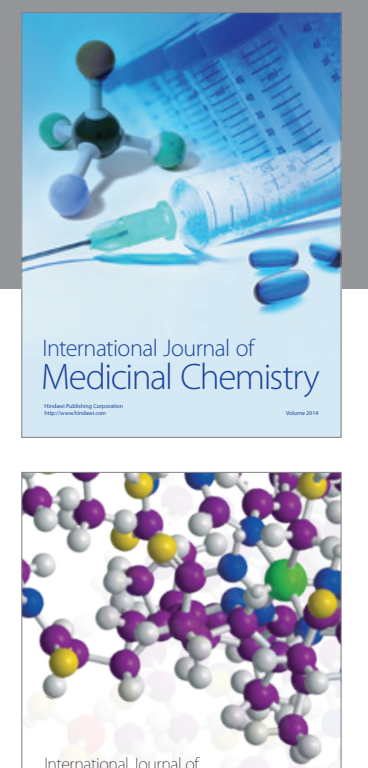

\section{Carbohydrate} Chemistry

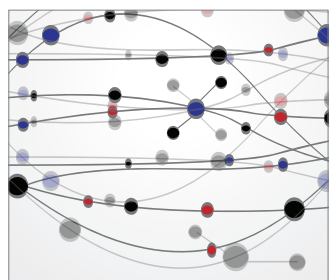

The Scientific World Journal
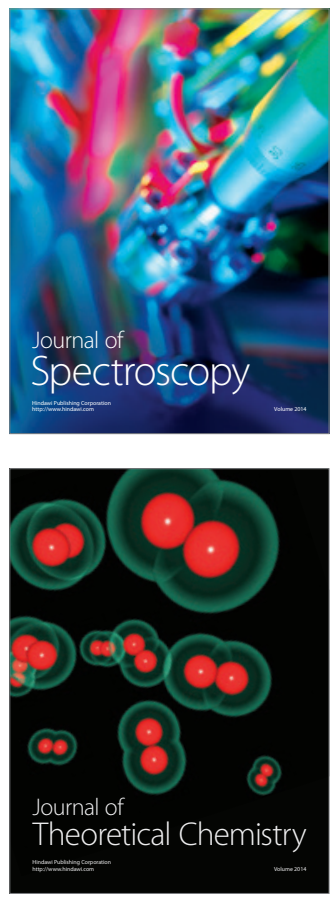
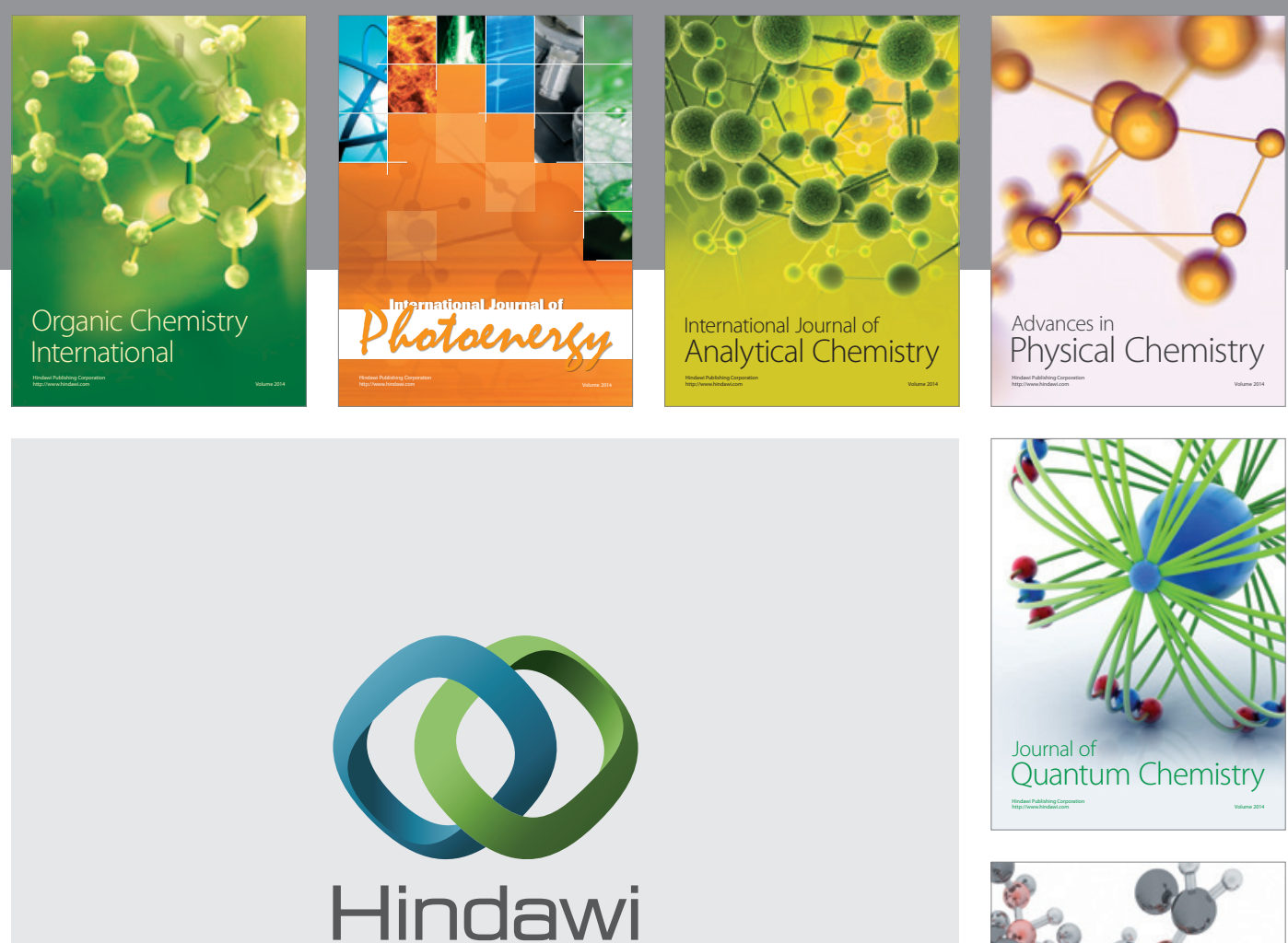

Submit your manuscripts at

http://www.hindawi.com

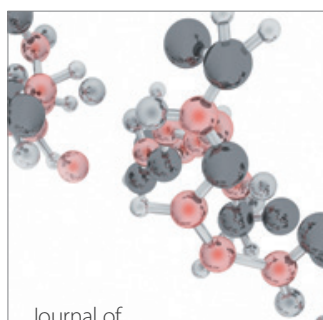

Analytical Methods

in Chemistry

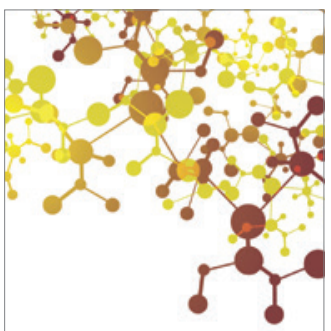

Journal of

Applied Chemistry

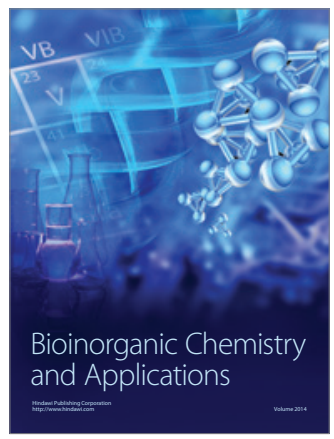

Inorganic Chemistry
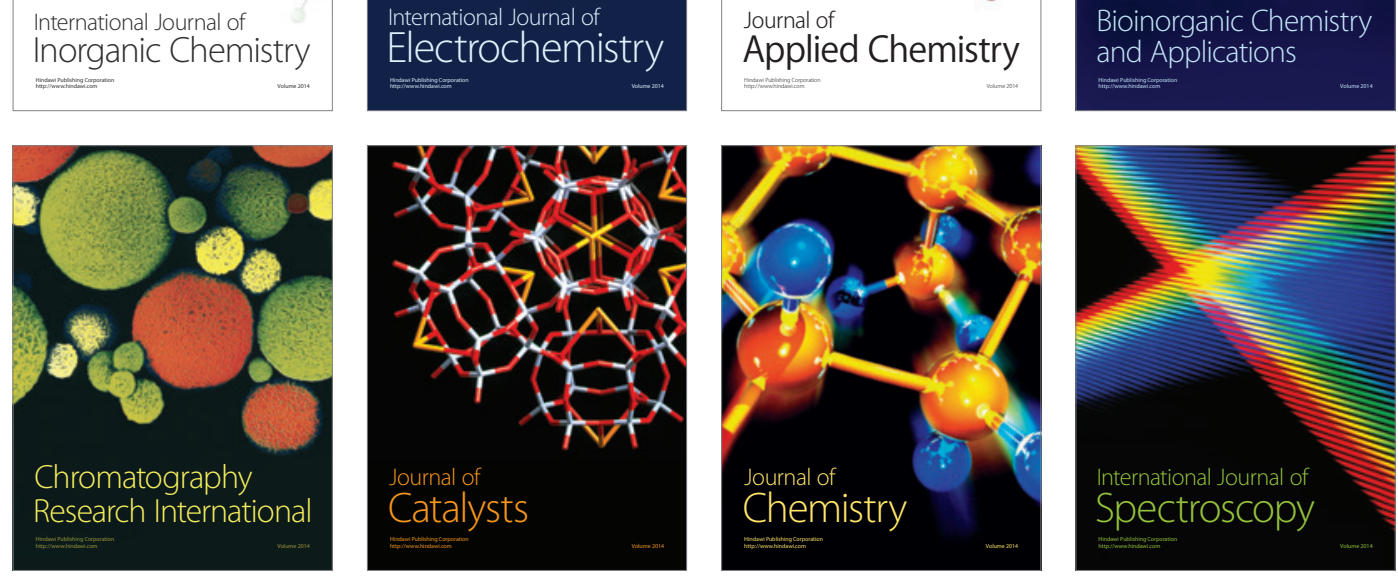